\title{
Australian Journal of \\ Effect of Trichoderma spp. fungus for production of seedlings in Enterolobium Schomburgkii (Benth.) Benth
}

\author{
Misael Freitas dos Santos ${ }^{1}$, Daniele Lima da Costa ${ }^{1}$, Thiago Almeida Vieira ${ }^{2}$, Denise Castro Lustosa ${ }^{2 *}$ \\ ${ }^{1}$ Postgraduate Program in Forestry Sciences, Midwestern State University, Brazil \\ ${ }^{2}$ Institute of Biodiversity and Forests, Federal University of Western Pará, Brazil
}

*Corresponding author: denise.lustosa@ufopa.edu.br

\begin{abstract}
Enterolobium schomburgkii (monkey ear) is important Amazonic forest specie, being used for wood and medicinal purposes and environmental recuperation issues. Biological treatment such as Trichoderma fungus is alternative method that may improve performance of seeds germination and provide healthy seedlings. We aimed to assess effect of Trichoderma fungus on development of E. schomburgkii seedlings. Five isolates of Trichoderma spp., in the concentration of $1.0 \times 10^{7} \mathrm{conidia}^{-1} \mathrm{~mL}^{-1}$, were assessed and applied through four methods: seeds; pre-planting substrate; post-planting substrate; and seed + pre-planting + post-planting substrate. The seedlings were produced in polypropylene bags and kept in nursery for 10 months. The experimental design was completely randomized, in a 5x4+1 factorial scheme, with 10 repetitions. We monthly assessed the plant height, collar diameter and number of leaves and leaflets. After 10 months, we assessed root length, dry matter of aerial part and dry matter of roots system. The results showed that variables were significantly influenced by Trichoderma isolates and its application modes, either individually or under interaction, except on the root length. Eight treatments boosted the plants height and five of them increased the collar diameter, compared with the control. The height of the seedlings was the variable that mostly influenced by the treatments. Application of Trichoderma in pre-planting substrate influenced the highest number of variables analyzed. Therefore, the isolates application used in this work is feasible for production of Enterolobium schomburgkii seedlings. Based on results of this experiment we do not recommended treatment of Enterolobium schomburgkii seeds with Trichoderma isolates, except using T. asperellum T09
\end{abstract}

Keywords: Native forest species; fungi; seeds; biological treatment; forest tree nursery. Abbreviations: T09_Trichoderma asperellum 09, T12_Trichoderma asperellum 12, T52_Trichoderma asperellum 52, Tc_Trichoderma sp. c, Tce_Trichoderma sp.ce.

\section{Introduction}

Biological treatment is based on the use of microorganisms or its metabolites to protect seeds, promote germination and vegetative growth and to control different pathogens (Menten and Moraes, 2010). It is one of the alternative methods that may guarantee profitability of the producer's activity. At the same time, it minimizes application of chemical products since they may cause damage to the environment and affect negatively human health (Lucon, 2009, Cruz, 2010).

The gender Trichoderma stands out between the microorganisms which may be used in biological treatment. It is a fungus present in all types of soils and in other environments, as rhizosphere, organic matter, etc. (Harman et al., 2004). It has raised huge scientific interest in the recent years (Pomella and Ribeiro, 2009). It presents different action mechanisms to promote biocontrol as: antibiosis, micro-parasitism, competition, resistance induction, predation, hypovirulence and inactivation of phytopathogen enzymes, in addition to provide higher efficiency for absorption and use of some nutrients, improving availability
(Silva and Mello, 2005; Santin, 2008; Dias, 2011; Machado et al., 2012). Species of Trichoderma are also used as plants growth promoters, including the beneficial effects for germination of seeds, emergence and development of plantlets, as well as, grains and fruits production (Santos, 2008).

Despite the invaluable contribution of Trichoderma species for agricultural crops, few studies have been realized involving these antagonistic fungi in native forest species (Donoso et al., 2008). However, its application is also feasible in forest areas, particularly in seedling nursery, where the environmental conditions may be controlled (Fortes et al., 2007). Results of this interaction could optimize seedlings production for the most diverse interests and, as a consequence, could reduce forest resources extraction (Machado et al., 2015), once the lack of technical guidance and lack of ecological awareness on forest resources exploration in Brazil have resulted in irreparable damage. In many cases, it has caused extinction of native species with huge ecological value (Lorenzi, 2013), 
Besides, many of these species has importance for their wood and industrial quality, medicinal and landscape use (Arraes et al., 2012; Junges et al., 2016).

In this context, the species Enterolobium schomburgkii (Benth.) Benth stands out since it is a forest product whose wood has significant economic value, used in constructions and woodworking (Gonçalez and Gonçalves, 2001; Lorenzi, 2013), and whose leaves are indicated for cancerous tumors treatment (Esposito-Avella et al., 1985). Furthermore, species from the genus Enterolobium are widely indicated to be planted in cities and for restoration of degraded areas, due to its rapid initial growth (Cargnelutti Filho et al., 2018). Thus, this work aimed to evaluate the effect of biological treatment with five isolates of Trichoderma in the development of $E$. schomburgkii seedlings. Biological treatment with species of this fungal genus is widely used in agricultural species, but with few reports on forest species, especially those native to the Amazon. In addition, its use may decrease the dependence of chemical inputs and contribute to the initial development of plants and can act as an effective biological control agent.

\section{Results}

\section{Effect of the biological treatment over variables}

There were significant effects $(p \leq 0.05)$ of the factors, separately (Trichoderma and application methods) or in interaction on plant height, collar diameter, number of leaflets, dry matter of aerial part. Also, and a significant effect of the factor Trichoderma to the root length was observed by Tukey's test, as well as a significant effect of the control vs factorial, for the same variables, using Dunnett's test ( $p \leq 0.05)$. At least eight treatments increased the plant height. Three treatments reduced the root length, compared with the control treatment. For collar diameter, number of leaflets and dry matter of aerial part we observed five, four and three treatments diverging from the control, respectively (Table 1 ). Application of Trichoderma in pre-planting substrate influenced the largest number of variables analyzed, compared with the other treatments and to the control (Table 1). Three of the five fungi tested caused an increase in at least one of the variables. The isolate of Trichoderma Tce had a positive effect on plant height, collar diameter, number of leaflets and dry mass of aerial part, when it was used the pre-planting application.

The fungi $T$. asperellum T12 and T52 were also applied in pre-planting substrate provided an increase in seedlings height of $30.5 \%$ and $31 \%$, respectively, compared to the control. Tce fungus occasioned the highest increments for collar diameter and dry mass of aerial part, with values of $27 \%$ and $57 \%$, respectively.

The seedlings treated with $T$. asperellum T09 applied to the seeds and, the ones treated with Trichoderma sp. Tce and $T$. asperellum T52, both applied in the pre-planting substrate increased the number of leaflets in $47 \%, 47 \%$ and $54 \%$, respectively. The isolate $\mathrm{T} 52$ increased the number of leaflets by 2.2 times, compared to the control.

Only fungus $T$. asperellum T09 caused positive effect on collar diameter, number of leaflets and dry mass of the aerial parts. However, when the same fungus was applied to the seeds and monthly applied in the post-planting substrate, we observed a reduction in the root length of $E$. schomburgkii, compared to the control. The $T$. asperellum T52 isolate also reduced this variable (Table 1), when applied monthly on the post-planting substrate. The reductions in root length of seedlings varied from $11.3 \mathrm{~cm}$ to $12.8 \mathrm{~cm}$ compared to the control.

\section{Comparison between Trichoderma isolates and modes of application}

Considering the isolates of Trichoderma T09 and Tc, the comparison between the averages of the treatments in the interaction of the factors (Trichoderma isolates $x$ application methods) showed that the application methods did not differ from each other for any of variables analyzed (Tukey's test). The lowest average values for height, collar diameter and number of leaflets were observed in the seedlings whose seeds were treated with $T$. asperellum T12 fungus (Table 2). The difference in height caused by this treatment ranged from $6.3 \mathrm{~cm}$ to $12.1 \mathrm{~cm}$, whereas for the collar diameter ranged from $0.5 \mathrm{~cm}$ to $1.1 \mathrm{~cm}$, while the number of leaflets ranged from 27 to 121 .

\section{Discussion}

It is possible to observe that the variables assessed did not follow similar behavior for all the treatments. According to Junges et al. (2016), this heterogeneity of response may be related to the fact that Trichoderma fungus exhibits variability among the strains, compared with: biocontrol activities, host action spectrum, physiological and biochemical properties, and ecological and environmental adaptability, influencing its performance as a bioprotective agent and as a growth promoter.

The increase in plant height provided by Trichoderma isolates demonstrates the importance of biological treatment in seedlings production. Results similar to this study were also found by Pereira (2017) for T. asperellum, when used as growth promoter for seedlings of Pinus taeda, 150 days after planting. Amaral et al. (2017) assessed seedlings of Jacaranda micrantha, using the same fungal species, 90 days after planting. Donoso et al. (2008), also noted that Trichoderma harzianum promoted the highest mean of height for plantlets of Pinus radiata.

In certain cases, some Trichoderma isolates may act negatively on seedlings development depending on the application method, as observed in the application of $T$. asperellum T12 through seeds. Similar results were observed at the application of Trichoderma sp. through seeds, with damage to emergence of plantlets of Parapiptadenia rigida (Junges et al., 2016).

Corroborating the results observed in this study, Amaral et al. (2017) concluded that the isolates of Trichoderma asperelloides and Trichoderma virens caused a significant increase in collar diameter of seedlings of J. micrantha, 90 days after planting. This variable is one of the most frequently used to indicate the survival capacity of seedlings in field (Daniel et al., 1997), once huge correlation between the seedlings survival percentage after planting in field, and the collar diameter were observed (Souza et al., 2006).

No reports were found on effect of Trichoderma on the leaflets number of native forest species seedlings. Therefore, the results obtained in this study are of great importance, since they show that application of Trichoderma can influence this variable, implying better photosynthetic rates, 
Table 1. Average plant height (AH), collar diameter (CD), number of leaves (NF), number of leaflets (NL), root length (RL), dry mass of aerial part (DMAP) and root dry mass (RDM) for seedlings of Enterolobium schomburgkii (Benth.) Benth submitted to different application methods of five isolates of Trichoderma spp., at 10 months after planting.

\begin{tabular}{|c|c|c|c|c|c|c|c|}
\hline Treatments & $\mathrm{AH}(\mathrm{cm})$ & $\mathrm{CD}(\mathrm{mm})$ & NF & $\mathrm{NL}$ & $\mathrm{RL}(\mathrm{cm})$ & DMAP $(g)$ & $\mathrm{RDM}(\mathrm{g})$ \\
\hline T09 - applied to the seeds & $28.9^{\text {ns }}$ & $3.5^{* *}$ & $10.7^{\text {ns }}$ & $121.4^{*}$ & $26.6^{*}$ & $3.0^{*}$ & $2.7^{\text {ns }}$ \\
\hline T09 - applied to pre-planting substrate & $28.8^{\mathrm{ns}}$ & $3.3^{\mathrm{ns}}$ & $9.0^{\mathrm{ns}}$ & $104.2^{\mathrm{ns}}$ & $32.7^{\text {ns }}$ & $2.7^{\mathrm{ns}}$ & $2.0^{\mathrm{ns}}$ \\
\hline T09 - monthly applications on post-plant substrate & $30.2^{* *}$ & $3.4^{* *}$ & $8.8^{\text {ns }}$ & $112.6^{\mathrm{ns}}$ & $28.1^{*}$ & $2.4^{\mathrm{ns}}$ & $2.1^{\text {ns }}$ \\
\hline $\begin{array}{l}\text { T09 - applied to seeds }+ \text { pre-planting substrate }+ \text { monthly } \\
\text { applications }\end{array}$ & $29.9^{* *}$ & $2.9^{\text {ns }}$ & $8.2^{\mathrm{ns}}$ & $102.7^{\mathrm{ns}}$ & $35.5^{\text {ns }}$ & $2.3^{\text {ns }}$ & $1.5^{\mathrm{ns}}$ \\
\hline T12 - applied to the seeds & $16.4^{\mathrm{ns}}$ & $2.4^{\mathrm{ns}}$ & $8.1^{\mathrm{ns}}$ & $52.7 \mathrm{~ns}$ & $36.8^{\text {ns }}$ & $1.0^{\mathrm{ns}}$ & $0.8^{\mathrm{ns}}$ \\
\hline T12 - monthly applications on pre-planting substrate & $31.8^{* *}$ & $3.1^{\mathrm{ns}}$ & $9.2^{\mathrm{ns}}$ & $101.8^{\mathrm{ns}}$ & $37.5^{\mathrm{ns}}$ & $2.3^{\mathrm{ns}}$ & $1.4^{\mathrm{ns}}$ \\
\hline T12 - applied to post-planting substrate & $25.2^{\text {ns }}$ & $3.0^{\text {ns }}$ & $9.3^{\text {ns }}$ & $90.2^{\text {ns }}$ & $34.4^{\mathrm{ns}}$ & $2.0^{\text {ns }}$ & $1.8^{\mathrm{ns}}$ \\
\hline $\begin{array}{l}\text { T12 - applied to seeds }+ \text { pre-planting substrate }+ \text { monthly } \\
\text { applications }\end{array}$ & $24.0^{\text {ns }}$ & $2.7^{\mathrm{ns}}$ & $8.7^{\mathrm{ns}}$ & $66.1^{\text {ns }}$ & $33.7^{\text {ns }}$ & $1.3^{\text {ns }}$ & $0.7^{\mathrm{ns}}$ \\
\hline T52 - applied to the seeds & $23.1^{\mathrm{ns}}$ & $2.9^{\mathrm{ns}}$ & $9.3^{\mathrm{ns}}$ & $80.6^{\text {ns }}$ & $30.5^{\mathrm{ns}}$ & $1.7^{\mathrm{ns}}$ & $1.2^{\mathrm{ns}}$ \\
\hline T52 - monthly applications on pre-planting substrate & $31.9^{* *}$ & $3.3^{\mathrm{ns}}$ & $9.5^{\mathrm{ns}}$ & $147.0^{*}$ & $26.7^{*}$ & $3.2^{*}$ & $1.9^{\mathrm{ns}}$ \\
\hline T52 - applied to post-planting substrate & $26.5^{\mathrm{ns}}$ & $3.3^{\mathrm{ns}}$ & $9.8^{\mathrm{ns}}$ & $105.4^{\mathrm{ns}}$ & $36.0^{\text {ns }}$ & $2.5^{\mathrm{ns}}$ & $2.1^{\mathrm{ns}}$ \\
\hline $\begin{array}{l}\text { T52 - applied to the seeds }+ \text { pre-planting substrate }+ \text { monthly } \\
\text { applications }\end{array}$ & $30.9^{* *}$ & $3.3^{*}$ & $9.4^{\mathrm{ns}}$ & $102.7^{\mathrm{ns}}$ & $33.4^{\mathrm{ns}}$ & $2.3^{\mathrm{ns}}$ & $1.3^{\text {ns }}$ \\
\hline Tc - applied to the seeds & $28.0^{\text {ns }}$ & $3.3^{\mathrm{ns}}$ & $10.5^{\mathrm{ns}}$ & $107.6^{\mathrm{ns}}$ & $33.7^{\text {ns }}$ & $2.6^{\text {ns }}$ & $2.2^{\mathrm{ns}}$ \\
\hline Tc - monthly applications on pre-planting substrate & $27.0^{\text {ns }}$ & $3.3^{\text {ns }}$ & $9.8^{\mathrm{ns}}$ & $100.9^{\text {ns }}$ & $29.6^{\text {ns }}$ & $2.2^{\mathrm{ns}}$ & $1.5^{\mathrm{ns}}$ \\
\hline Tc - monthly applications on post-planting substrate & $29.5^{* *}$ & $3.3^{\mathrm{ns}}$ & $9.9^{\text {ns }}$ & $127.0^{*}$ & $35.9^{\text {ns }}$ & $2.7^{\mathrm{ns}}$ & $2.4^{\mathrm{ns}}$ \\
\hline $\begin{array}{l}\text { Tc }- \text { applied to the seeds }+ \text { pre-planting substrate }+ \text { monthly } \\
\text { applications }\end{array}$ & $30.8^{* *}$ & $3.5^{* *}$ & $9.5^{\mathrm{ns}}$ & $104.0^{\mathrm{ns}}$ & $32.6^{\mathrm{ns}}$ & $2.6^{\mathrm{ns}}$ & $2.0^{\mathrm{ns}}$ \\
\hline Tce - applied to the seeds & $25.4^{\mathrm{ns}}$ & $3.1^{\mathrm{ns}}$ & $9.9^{\text {ns }}$ & $79.8^{\text {ns }}$ & $35.7^{\text {ns }}$ & $1.9^{\text {ns }}$ & $1.7^{\mathrm{ns}}$ \\
\hline Tce - monthly applications on pre-planting substrate & $31.1^{* *}$ & $3.7^{* *}$ & $9.4^{\mathrm{ns}}$ & $127.0^{*}$ & $31.0^{\mathrm{ns}}$ & $3.5^{*}$ & $2.6^{\mathrm{ns}}$ \\
\hline Tce - monthly applications on post-planting substrate & $21.7^{\text {ns }}$ & $2.9^{\mathrm{ns}}$ & $9.5^{\mathrm{ns}}$ & $80.7^{\text {ns }}$ & $41.3^{\text {ns }}$ & $1.9^{\mathrm{ns}}$ & $1.5^{\mathrm{ns}}$ \\
\hline $\begin{array}{l}\text { Tce }- \text { applied to the seeds pre-planting substrate }+ \text { monthly } \\
\text { applications }\end{array}$ & $24.8^{\mathrm{ns}}$ & $3.0^{\mathrm{ns}}$ & $9.3^{\text {ns }}$ & $79.8^{\text {ns }}$ & $35.6^{\mathrm{ns}}$ & $1.9^{\mathrm{ns}}$ & $1.2^{\mathrm{ns}}$ \\
\hline CONTROL & 22.1 & 2.7 & 8.5 & 67.7 & 39.4 & 1.5 & 1.2 \\
\hline
\end{tabular}

Table 2. The variables: height, collar diameter, number of leaflets and dry mass of aerial part for seedlings of Enterolobium schomburgkii (Benth.) Benth were submitted to different application methods of five isolates of Trichoderma sp., 10 months after planting.

\begin{tabular}{|c|c|c|c|c|}
\hline \multirow{3}{*}{$\begin{array}{l}\text { Isolates of } \\
\text { Trichoderma }\end{array}$} & \multicolumn{4}{|c|}{ Application method } \\
\hline & Seeds ${ }^{1}$ & Substrate $^{2}$ & Monthly applications ${ }^{3}$ & $\begin{array}{c}\text { Seeds }^{1}+\text { Substrate }^{2}+\text { Monthly } \\
\text { applications }^{3}\end{array}$ \\
\hline & & & Plants height $(\mathrm{cm})$ & \\
\hline T12 & $16.8 \mathrm{bC}$ & $31.8 \mathrm{aA}$ & $25.2 \mathrm{abB}$ & $24.0 \mathrm{bB}$ \\
\hline T52 & $23.1 \mathrm{aB}$ & $31.9 \mathrm{aA}$ & $26.5 \mathrm{abAB}$ & 30.9 aA \\
\hline \multirow[t]{2}{*}{ CV (\%) } & & & & 20.0 \\
\hline & \multicolumn{4}{|c|}{ Collar diameter $(\mathrm{mm})$} \\
\hline T09 & $3.5 \mathrm{aA}$ & $3.4 \mathrm{aA}$ & $3.4 \mathrm{aA}$ & $2.9 \mathrm{abA}$ \\
\hline $\mathrm{T} 12$ & $2.4 \mathrm{bB}$ & $3.2 \mathrm{aA}$ & $3.0 \mathrm{aAB}$ & $2.7 \mathrm{bAB}$ \\
\hline T52 & $2.9 \mathrm{abA}$ & $3.4 \mathrm{aA}$ & $3.3 \mathrm{aA}$ & $3.3 \mathrm{abA}$ \\
\hline T09 & $121.4 \mathrm{aA}$ & $104.2 \mathrm{aA}$ & $112.6 \mathrm{aA}$ & $102.7 \mathrm{aA}$ \\
\hline T12 & 52.7 bB & $101.8 \mathrm{aA}$ & $90.2 \mathrm{aAB}$ & $66.1 \mathrm{aAB}$ \\
\hline T52 & $80.6 \mathrm{abB}$ & $147.0 \mathrm{aA}$ & $105.4 \mathrm{aAB}$ & $102.7 \mathrm{aAB}$ \\
\hline Tc & $107.6 \mathrm{aA}$ & $100.9 \mathrm{aA}$ & $127.0 \mathrm{aA}$ & $104.0 \mathrm{aA}$ \\
\hline Tce & 79.8 bB & $127.0 \mathrm{aA}$ & $80.7 \mathrm{aB}$ & $79.8 \mathrm{aB}$ \\
\hline \multirow[t]{2}{*}{ CV (\%) } & & & & 39.8 \\
\hline & \multicolumn{4}{|c|}{ Dry mass of aerial part } \\
\hline T09 & $3.0 \mathrm{aA}$ & $2.7 \mathrm{abA}$ & $2.4 \mathrm{aA}$ & $2.3 \mathrm{abA}$ \\
\hline $\mathrm{T} 12$ & $0.9 \mathrm{cB}$ & $2.3 \mathrm{abA}$ & $1.9 \mathrm{aAB}$ & $1.3 \mathrm{bAB}$ \\
\hline T52 & $1.7 \mathrm{bcB}$ & $3.2 \mathrm{abA}$ & $2.5 \mathrm{aAB}$ & $2.3 \mathrm{abAB}$ \\
\hline Tc & $2.6 \mathrm{abA}$ & $2.2 \mathrm{bA}$ & $2.7 \mathrm{aA}$ & $2.6 \mathrm{aA}$ \\
\hline
\end{tabular}


for example. According to Costa et al. (2012), leaves and leaflets contribute to a greater photosynthetic activity, supplying the plants in terms of energy and contributing to their development.

No significant difference was observed on the number of leaves, compared to the control. Some studies show this variable may be positively influenced by application of Trichoderma. Machado et al. (2015) observed an increment in number of leaves, when the effect of isolates of Trichoderma harzianum was assessed on seedlings of Gochnatia polymorpha, at 84 days after planting. The same was observed on Junges et al. (2016) analyzing the effect of Trichoderma sp. on seedlings of Pelptophorum dubium.

Corroborating with results related to the gains in the aerial part biomass of plants obtained in this work using isolates of Trichoderma, Amaral et al. (2017) assessed the effect of Trichoderma asperelloides on seedlings of Jacaranda micrantha, 90 days after sowing. They verified an average gain of $129.8 \mathrm{mg}$ in dry mass with application of this fungus, compared to control seedlings, which resulted in an average of $48.2 \mathrm{mg}$. Carvalho Filho et al. (2008), tested the isolate CEN 162 of $T$. asperellum and the isolate CEN 262 of T. harzianum to promote seedlings growth of a hybrid eucalyptus clone. They observed the highest mean for root dry mass and for aerial part in the seedlings treated with these fungi. Resende et al. (2004) also verified a higher accumulation of dry matter in seedlings of corn (Zea mays) treated with T. harzianum.

According to Aguiar et al. (2015), the production of metabolites by fungi of the genus Trichoderma could promote seedlings growth, since they can stimulate the multiplication of plant cells, and consequently increase the biomass of the plants. Different isolates of Trichoderma sp. promote direct effects on plants, increasing their growth potential and nutrient uptake, affecting the production of biomass (Shoresh et al., 2010).

Although there was a reduction in root length of the plants treated with isolates of $T$. asperellum TO9 (seeds and substrate after planting) and T52 (substrate after planting), these treatments did not compromise the final development of the seedlings, besides providing positive results on other variables, when applied in different ways. The plant roots can be considered as one of the most important parts for the interaction with the isolates of Trichoderma, where the fungi interference in plant growth and productivity increase occurs due to their ability to colonize the plants.

The results obtained for application of Trichoderma isolates in the pre-planting substrate are very favorable, because this mode of application is easy to use and can be applied by the producers. According to Junges et al. (2016), the presence of the bioprotector in the substrate may be fundamental for the plant development after planting or transplant, when the seedlings are more exposed to pathogens. The ability of Trichoderma fungi to promote plant development may be related to their capacity for symbiotic association with plant roots, and with its decomposing action, providing absorbable nutrients to the plants, as well as the ability as biocontrol agent, inhibiting phytopathogens action. This can interfere directly the normal development of the plant (Santos, 2008).

\section{Materials and methods}

\section{Plant materials}

The study was developed at Phytopathology Laboratory in the Forest Nursery of the Institute of Biodiversity and Forests (Ibef), in Federal University of Western Pará (Ufopa), in the municipality of Santarém, Pará, Brazil. The E. schomburgkii seeds were collected from the following coordinates (2 $25^{\prime} \mathrm{S}$ and 54은 $44^{\prime}$ W).

Due to the low percentage of germination obtained in the pre-test $(14.3 \%)$, seeds of E. schomburgkii were previously scarified in a rotary scarifier to set up the experiment, for a period of seven seconds, according to the methodology adapted from Souza and Varela (1989).

The planting was carried out in polypropylene bags with capacity for $2.25 \mathrm{~kg}$ of substrate. The seeds were sown at a depth of about $0.5 \mathrm{~cm}$. After planting, the bags were put in plant beds covered with a shade net to block out $30 \%$ of light. At the dry season, the seedlings were daily irrigated. Forest soil (not sterilized) was the substrate.

\section{Treatments and experimental design}

The effects of five isolates of Trichoderma spp. were assessed on the development of $E$. schomburgkii seedlings. Three of the samples were belong to the species Trichoderma asperellum: T09, T12 and T52, obtained from the city of Urucu, Amazonas, Brazil. Two of Trichoderma sp., Tc and Tce, were obtained from Agroforestry system, located in Santarém (species not yet identified).

All fungi were mass produced in parboiled rice grains for assembling and subsequent testing steps, which consisted of the following treatments: (a) seeds treatment; (b) application in the substrate before planting; (c) monthly application in the substrate after planting; and (d) seeds treatment + application in the substrate before planting + monthly application in the substrate after planting.

Seed treatment consisted of immersion in fungal suspension prepared with each one of the Trichoderma isolates, in concentration of $1.0 \times 10^{7}$ conidia. $\mathrm{mL}^{-1}, 24$ hours before planting. For pre-planting application we used $10 \mathrm{~g}$ of rice per kilo of substrate (colonized by isolates of Trichoderma) followed by substrate homogenization. At the monthly post-planting applications of Trichoderma spp., each seedling was irrigated with $10 \mathrm{~mL}$ of an $1.0 \times 10^{7}$ conidia. $\mathrm{mL}^{-1}$ suspension, prepared for each isolate, considering the first application was realized at day 15 after planting. Referring to the combination of the three methods to propagate the isolates of Trichoderma, the treatment was realized through previous applications in the seeds and in the pre-planting substrate, followed by monthly applications of fungal suspensions in the post-planting substrate. Control treatment consisted of cultivation without application of the Trichoderma isolates.

The experimental design was completely randomized, in a $5 \times 4+1$ factorial scheme (5 Trichoderma isolates $\times 4$ application methods +1 control treatment), with 10 repetitions, resulting in a total of 210 seedlings. 


\section{Traits measured}

The following variables were monthly assessed: (a) plant height, distance measure between collar and apex of leaves set, (b) collar diameter, measured with digital pachymeter and, (c) number of leaves and leaflets, accounted per plant. At the end of the experiment (10 months), the dry matter of aerial part and the dry matter of the root system were obtained measuring the root length with millimeter scale ruler, after drying the plants in a forced circulation greenhouse at $45{ }^{\circ} \mathrm{C}$, during 40 hours and weighing of vegetable matter, in a precision scale.

\section{Statistical analysis}

These analyses were performed using the $R$ 3.5.1 ( $R$ Core Team, 2016). The averages acquired in the treatments were compared through Tukey's test $(p \leq 0.05)$ and the comparison between the treatments averages and the control was done through Dunnett's test $(p \leq 0.05)$.

\section{Conclusion}

The isolates of Trichoderma were assessed through different application methods. They caused positive effects in at least three of the variables analyzed, with exception of Trichoderma sp. T12. The height of the seedlings was the variable most influenced by the treatments. The application of Trichoderma isolates in pre-planting substrate influenced the largest number of variables analyzed. In general we do not recommend treatment of $E$. schomburgkii seeds with Trichoderma isolates, except for T. asperellum T09. The applications of Trichoderma isolates used in this work are feasible for utilization in seedlings production of $E$. schomburgkii.

\section{Acknowledgement}

Thank to Federal University of Western Pará (Ufopa) for costing Scientific Initiation Scholarship to the first author.

\section{References}

Aguiar AR, Aguiar D, Tedesco SB, Silva ACF (2015) Efeito de metabólitos produzidos por Trichoderma spp. sobre o índice mitótico em células das pontas de raízes de Allium cepa. Biosci J. 31: 934-940.

Amaral PP, Steffen GPK, Maldaner J, Missio EL, Saldanha CW (2017) Promotores de crescimento na propagação de caroba. Pesq flor bras. 37: 149-157.

Arraes RA, Mariano FZ, Simonassi AG (2012) Causas do Desmatamento no Brasil e seu ordenamento no contexto mundial. RESR. 50: 119-140.

Cargnelutti Filho A, Araujo MM, Gasparin E, Foltz DRB (2018) Dimensionamento Amostral para Avaliação de Altura e Diâmetro de Plantas de Timbaúva. Floresta Ambient. 25: 1-9.

Carvalho Filho MR, Mello SCM, Santos RP, Menêzes JE (2008) Avaliação de isolados de Trichoderma na promoção de crescimento, produção de Ácido Indolacético in vitro e Colonização Endofítica de mudas de Eucalipto, Embrapa Recursos Genéticos e Biotecnologia, Brasília. $16 p$.

Costa MS, Alves SMC, Ferreira Neto M, Batista RO, Costa LLB, Oliveira WM (2012) Produção de mudas de timbaúba sob diferentes concentrações de efluente doméstico tratado. Irriga 1: 408-422.

Cruz JLG (2010) Efeito de Trichoderma spp. no potencial fisiológico de sementes e mudas de melão. Masters dissertation. Universidade Federal de Santa Maria, Santa Maria. $64 \mathrm{p}$.

Daniel O, Vitorino ACT, Alovisi AA, Mazzochin L, Tokura AM, Pinheiro ER, Souza EF (1997) Aplicação de fósforo em mudas de Acacia mangium Willd. Rev Árvore. 21: 163-168.

Dias PP (2011) Controle biológico de fitopatógenos de solo por meio de isolados de fungos do gênero Trichoderma e sua contribuição para do crescimento de plantas. Doctor thesis. Universidade Federal do Rio de Janeiro, Seropédica. 101 p.

Donoso E, Lobos GA, Rojas N (2008) Efecto de Trichoderma harzianum y compost sobre el crecimiento de plántulas de Pinus radiata em viveiro. Bosque. 29: 52-57.

Esposito-Avella M, Brown P, Tejeira I, Buitrago R, Barrios L, Sanchez C, Gupta MP, Cedeno J (1985) Pharmacological screening of Panamanian medicinal plant, Part I. Int J Crude Drug Res. 23: 17-25.

Fortes FO, Silva ACF, Almança MAK, Tedesco SB (2007) Promoção de enraizamento de microestacas de um clone de Eucalyptus sp. por Trichoderma spp. Rev Árvore. 31: 221-228.

Gonçalez JC, Gonçalves DM (2001) Valorização de duas espécies de madeira Cedrelinga catenaeformis e Enterolobium schomburgkii para a indústria madeireira. Brasil Florestal. 70: 69-74.

Harman GE, Howell CR, Viterbo A, Chet I, Lorito M (2004) Trichoderma species - opportunistic, avirulent plant symbionts. Nature. 2: 43-56.

Junges E, Muniz MF, Mezzomo R, Bastos B, Machado RT (2016) Trichoderma spp. na produção de mudas de espécies florestais. Floresta Ambient. 23: 237-244.

Lorenzi H (2013) Árvores brasileiras: manual de identificação e cultivo de plantas arbóreas nativas do Brasil. Plantarum, Nova Odessa, 640.

Lucon CMM (2009) Promoção de crescimento de plantas com o uso de Trichoderma spp. (em linha). Infobibos, Informações Tecnológicas. Disponível em: $<$ http://www.infobibos.com/Artigos/ 2009_1/trichoderma/index.htm> (Access in: 01 set. 2018).

Machado DFM, Parzianello FR, Silva ACF, Antoniolli ZI (2012) Trichoderma no Brasil: o fungo e o bioagente. Rev Cienc Agrar. 35: 274-288.

Machado DFM, Tavares AP, Lopes SJ, Silva ACF (2015) Trichoderma spp. na emergência e crescimento de mudas de cambará (Gochnatia polymorpha (Less.) Cabrera). Rev Árvore. 39:167-176.

Menten JO, Moraes MHD (2010) Avanços no tratamento e recobrimento de sementes tratamento de sementes: histórico, tipos, características e benefícios. Informativo ABRATES. 20:052-053.

Pereira FB (2017) Fungos Promotores de Crescimento e Produção de mudas de Pinus taeda L. Masters dissertation. Universidade Estadual do Centro-Oeste, Irati. 50 p.

Pomella AV, Ribeiro RS (2009) Controle Biológico com Trichoderma em Grandes Culturas - Uma visão empresarial. In: Bettiol W, Morandi MB (ed) Biocontrole de doenças deplantas: uso e perspectivas, 1. ed. Embrapa Meio Ambiente, Jaguariúna.

R Core Team (2016) R: a language and environment for statistical computing. R Foundation for Statistical 
Computing, Vienna, Austria. Disponible: <https://www.R-project.org/> Accessed: 15 Oct 2018.

Resende ML, Oliveira JA, Guimarães RM, Pinho RGV, Vieira AR (2004) Inoculação de sementes de milho utilizando o Trichoderma harzianum como promotor de crescimento. Ciênc agrotec. 28: 793-798.

Santin RCM (2008) Potencial do uso dos fungos Trichoderma spp. e Paecilomyces lilacinus no biocontrole de Meloidogyne incógnita em Phaseolus vulgares. Doctor thesis. Universidade Federal do Rio Grande de Sul, Porto Alegre. 91 p.

Santos HÁ (2008) Trichoderma spp. como promotores de crescimento em plantas e como antagonista a Fusarium oxysporum. Master dissertation. Universidade de Brasília, Brasília. $111 \mathrm{p}$.
Shoresh M, Harman GE, Mastouri F (2010) Induced systemic resistance and plant responses to fungal biocontrol agents. Annu Rev Phytopathol. 48: 21-43.

Silva JBT, Mello SCM (2007) Utilização de Trichoderma no Controle de Fungos Fitopatogênicos. Embrapa Recursos Genéticos e Biotecnologia, Brasília. 17 p.

Souza SGA, Varela VP (1989) Tratamentos prégerminativos em sementes de faveira-orelha-de-macaco (Enterolobium schomburgkii Benth.). Acta Amaz. 19: 19-26.

Souza CAM, Oliveira RB, Filho SM, Lima JSS (2006) Crescimento em campo de espécies florestais em diferentes condições de adubação. Cienc Florest. 16: 243-249. 